\title{
Influence of learning and working climate on the retention of talented employees
}

Natalie Govaerts and Eva Kyndt

Centre for Research on Teaching and Training, KU Leuven, Leuven, Belgium Filip Dochy

Centre for Research on Teaching and Training, KU Leuven, Leuven, Belgium and Centre for Educational Research on Lifelong Learning and Participation, KU Leuven, Leuven, Belgium, and

\author{
Herman Baert \\ Centre for Educational Research on Lifelong Learning and Participation, \\ KU Leuven, Leuven, Belgium
}

\begin{abstract}
Purpose - The aim of this study is to investigate some factors that have an influence on employee retention. Based on the literature and previous research, both employee and organisational factors are taken into account.

Design/methodology/approach - Data were collected by means of a questionnaire that was distributed on a voluntary basis in professional organisations and among employees, both electronically and in hard-copy, during 2008-2009. The study sample consisted of 972 employees, mainly clerks, from diverse profit and social-profit organisations.

Findings - The results show that when organisations want to retain their employees it is important to pay attention to the learning of employees. Letting people do more and learn more of what they are good at will encourage them to stay with the organisation. Results concerning the selected employee variables show that only age has a significant relationship with retention. Regarding the intention to stay, there exists a positive relationship between age and retention.

Research limitations/implications - A limitation of this study is that both employee as organizational factors are measured through the perceptions of employees. The response set of subjects when responding to self-report measures could therefore be the result of a temporary mood, or could be the result of what may be considered as socially appropriate by the participants. Another limitation is that the questionnaire was voluntarily completed by the respondents; the researcher had therefore no information about the non-respondents.
\end{abstract}

Originality/value - The paper focuses on the factors influencing employee retention.

Keywords Learning, Retention, Employees, work identity, Organizational culture

Paper type Research paper

Today's organisations are continuously confronted by social developments such as globalisation, technological improvements and increasing global competition. Companies have to be able to anticipate technological innovation and to compete with other companies worldwide (Burke and $\mathrm{Ng}$, 2006). Besides these economic evolutions, demographic changes are also putting pressure on companies. The current society has to deal with the rapid aging of the active population while, in the meantime, fewer young people are entering the labour market. In addition, the workers of the so-called baby boom generation are gradually retiring (Burke and $\mathrm{Ng}$, 2006; Frank et al.,
Influence of learning
Received 20 April 2010

Revised 7 July 2010

Accepted 17 September

2010

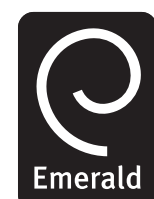

Journal of Workplace Learning Vol. 23 No. 1, 2011 pp. $35-55$

(C) Emerald Group Publishing Limited 1366-5626 DOI 10.1108/13665621111097245 
JWL 23,1

36
2004). These evolutions cause not only a shortage of workers, but also a risk of losing knowledge and experience, for which companies have to find an answer. This loss of knowledge and experience increases the importance of retaining talent. Lockwood (2006, p. 2) describes talent as "... the vehicle to move the organisation to where it wants to be". Accordingly, talent is becoming increasingly important and will continue to do so (Hiltrop, 1999). In the next two decades it will be the key corporate resource (Michaels et al., 2001). Because of demographic changes, the demand for talent will increase, while supply will decline. As a consequence, it is expected that a "war for talent" will emerge (Fishman, 1998). It therefore becomes increasingly important for organisations to retain talented and skilled employees in order to maintain their competitive advantage. Losing such employees means a loss of investment in that new employees have to be hired and trained. Moreover, employees take their know-how with them and thus the company risks a potential loss of confidential information to competitors (Frank et al., 2004; Walker, 2001).

Previous research has shown that the learning and development of employees is an important retention-supporting strategy (Abrams et al., 2008; Christiaensen et al., 2009; Kyndt et al., 2009; Van Hamme, 2009). This study will investigate employee and organisational factors that influence employee retention such as the learning and working climate. It will also look for some well selected differences in different kind of groups of employees with regard to their retention. These groups will be based on seniority, level of education and whether or not they are considered as having high potential.

\section{Theoretical background}

\subsection{Talent}

Talent leads to exceptional performances and talented people are often admired and valued. Talent is perceived as something valuable, rare and hard to imitate. However, an unambiguous definition of the concept does yet not exist. Nevertheless, to keep our focus clear, the following definition is central throughout this study: Talent is “... any innate capacity that enables an individual to display exceptionally high performance in a domain that requires special skills and training" (Simonton, 1999, p. 436). Even though there is no single definition of the concept of talent, there are some characteristics with regard to which consensus is readily reached when describing talent. The first concerns the contrast between nurture and nature. On the one hand, talent is viewed as a powerful, innate component (Echols, 2007) while, on the other hand, it is believed that factors from the environment, especially education and training, cause talent to emerge (Barab and Plucker, 2002). Increasingly, scholars come to agree that both have a say in the emergence of talent (Simonton, 1999).

Another characteristic is the dependence of talent on context. Context could be understood as both the social and economic environment, as well as the organisation and its specific needs. This context dependence, by responding to the context within which a company operates, influences talent and thereby secures the future of the company (Glen, 2007; Thorne and Pellant, 2007).

The third and final characteristic of talent is the potential for it being a strategic tool. Most business leaders understand that the use of talented employees to maximise business opportunities has become the most important factor in ensuring ongoing organisational success (Ingham, 2006). In addition, talent can also be a strategic tool for employees themselves. According to Bexell and Olofsson (2005), talent is a scarce 
resource, like capital, which can flow freely, seeking its best uses and greatest rewards. Hence, if employees keep learning and are flexible, they may go where they want to go, and command the money, opportunities and working conditions they desire.

Talented employees are of great value for companies (Hiltrop, 1999), but precisely which employees are talented? In the literature, two perspectives can be found. The first perspective makes a distinction between High Potentials and non High Potentials (Dries and Pepermans, 2007, 2008; Lombardo and Eichinger, 2000). High potential employees are defined as those who are recognised by senior management as persons with the potential to fulfil an executive function within the company (Cope, 1998; Dries and Pepermans, 2008; Pepermans et al., 2003). Several characteristics are attributed to these High Potentials such as intelligence, social skills, flexibility, stress resistance, team spirit, negotiation skills and proactivity (Conner, 2000; Lombardo and Eichinger, 2000; Pepermans et al., 2003; Snipes, 2005). Moreover, a few core characteristics of high potential employees can be discerned. These include creativity (Pepermans et al., 2003), leadership skills (Pepermans et al., 2003), learning potential (Conner, 2000; Lombardo and Eichinger, 2000) and autonomy (Dries and Pepermans, 2008; Snipes, 2005).

The second perspective is based on the following maxim: everyone has talent. In this view, talent is something that penetrates the entire company and is therefore never exclusively connected to one function. A company thus needs to consider the added value of every employee, and not only of those who occupy top positions in the company (Houtkamp and Maree, 2008). In this study, the latter perspective is central and therefore High Potentials as well as other employees have been included and examined.

\subsection{Employee retention}

The previously mentioned demographic and economic evolutions prompt organisations to focus increasingly on the retaining of talented employees. This process is known as retention and is very important for the future of a company. Frank et al. (2004, p. 13) define retention as "... the effort by an employer to keep desirable workers in order to meet business objectives". The directive for companies in this time of "war for talent" is to reduce turnover in favour of the retention of talented employees.

Previous research has identified several factors relating to employee retention, situated on both organisational and employee levels. On the organisational side, factors influencing retention appear to be the existence of challenging and meaningful work, opportunities for advancement, empowerment, responsibility, managerial integrity and quality and new opportunities/challenges (Birt et al., 2004). Walker (2001) also identified seven factors which can encourage retention-compensation and appreciation of the work performed; the provision of challenging work; opportunities to learn; positive relationships with colleagues; recognition of capabilities and performance contributions; good work-life balance; and good communication within the organisation. Echols (2007) states that, when combined with selective promotion and salary action, the learning and development process is a strong retention activity. Finally, Hytter (2007) demonstrated that workplace factors such as rewards, leadership style, career opportunities, training and development of skills, physical working conditions, and work-life balance, have an indirect influence on retention. The fact that effective training, and opportunities to learn and develop, enhance employee retention, is also confirmed by other researchers such as Arnold (2005), Herman (2005) and Hiltrop (1999). It can therefore be concluded that learning and development can be considered as

\section{Influence of learning}


JWL 23,1

38 important retention-enhancing strategies. Research has also shown that, as long as employees feel that they are learning and growing, they will be less inclined to leave. On the other hand, once employees feel they are no longer growing, they begin to look externally for new job opportunities (Rodriguez, 2008). This makes development and learning critical for attracting and retaining employees, because "[. . . talented people are inclined to leave if they feel they are not growing and stretching" (Michaels et al., 2001, p. 14). This body of research underpins surely the main ideas of organisational learning, stressing the importance of individual development in order for organisations to learn as a whole (Argyris, 2001; Gijbels and Spaenhoven, 2011; Peck et al., 2009).

There are, however, also factors at the employee level which affect the retention of employees. In previous research the role of certain employee variables such as age, seniority and level of education was investigated. However, results for these variables were rather inconclusive. In one study it was found that older people are more likely to remain working in an organisation, thus age has a positive influence on retention (Christiaensen et al., 2009), in other studies seniority was identified as having a positive influence on retention (Kyndt et al., 2009; Van Hamme, 2009). Only age and seniority are highly correlated, which means that, for now, a clear conclusion cannot be drawn. However, in the research by Gunz and Gunz (2007) work experience and tenure were found to have a positive influence on retention. Also, with regard to the level of education, results are not aligned. In some studies there is a significant negative relationship found between the level of education and retention (Christiaensen $e t$ al., 2009; Kyndt et al., 2009), but in other research (Abrams et al., 2008; Van Hamme, 2009), no such relation was found.

\subsection{Learning and working climate}

Since learning and development opportunities appear crucial for the retention of talented employees (Arnold, 2005; Echols, 2007; Herman, 2005; Hiltrop, 1999; Hytter, 2007; Michaels et al., 2001; Rodriguez, 2008; Walker, 2001), an organisation must establish a supportive learning and working climate. The concept "learning and working climate" is derived from previous research (Abrams et al., 2008; Birt et al., 2004; Bouwmans, 2006; Christiaensen et al., 2009; Kyndt et al., 2009; Van Hamme, 2009; Visser, 2001). In general it refers to the environment wherein employees both learn and work. More specifically, the concept could be described by referring to: guidance and appreciation at work; pressure of work; the amount of empowerment and the responsibility that employees experience; choice in job tasks and development; provision of challenging and meaningful work; and advancement and development opportunities.

In practice there are two approaches to the learning and working climate. The first, the gap approach, is the more traditional approach and emphasises what is lacking or wrong or what does not function well in an organisation. The process of problem solving generally starts with a diagnosis of the problem and results in a plan for intervention that can be implemented (Visser, 2001). Central to this is the comparison of the current situation with the desired position, which results in a list of deficits. As a consequence, such deficits should then preferably be eliminated by the introduction of learning activities (Verheijen and Dewulf, 2004). The second approach is the appreciative approach. In this approach the focus is not on analysing the problem and repairing the defect, but in finding and enhancing solutions that already exist (Visser, 2001). It is a very person-oriented approach wherein qualities and ambitions are the 
engine for the development process. The premise is that true talent, and not weaknesses, offer the most room for growth (Tjepkema and Verheijen, 2005). The appreciative approach is therefore a radically affirmative approach to change that completely lets go of problem-based management (Cooperrider and Whitney, 2005). Learning and development are used to further develop strengths and talents (Tjepkema and Verheijen, 2005).

Five key distinctions can be made between the gap and the appreciative approaches (Kyndt et al., 2009). The first distinction is situated at the domain of selection. During selection interviews, candidates are asked about their competences and talents. If the organisation checks whether or not these are suited to resolving their deficits, then this is consistent with the gap approach. If, however, the organisation checks as to whether the existing talent and its development can make the company stronger, an appreciative approach is applied. A second distinction concerns the development of the organisation and of individual employees. The appreciative approach focuses on what can make the company successful. Employees are supported in following their interests and in further developing their strengths and talents (Cooperrider et al., 2007). On the other hand, using the gap approach, a problem that prevents the accomplishment of organisational goals represents the reason for change. The training of employees only occurs when there is a shortage in competence or skills. The third distinction is related to the way problems are solved within the company. When employees are allowed to take the initiative, the company is operating an appreciative approach. When the company relies on already existing rules and procedures, consequently a gap approach is used. Fourth, both approaches differ in their appreciation of employees. The appreciative approach appreciates employees for their strengths, while the gap approach appreciates employees for fulfilling the current expectations of the company. Reflection and stimulation is the final area where differences between the gap and the appreciative approach can be identified. When the reflection processes focus on deficiencies with respect to the current situation, the gap approach is more dominant, whereas the appreciative approach focuses more on strengths of the employees and is more directed towards new opportunities (Kyndt et al., 2009).

Results from previous research show that the appreciative approach, operationalised through an appreciative learning and working climate, positively influences employee retention (Abrams et al., 2008; Christiaensen et al., 2009; Kyndt et al., 2009; Van Hamme, 2009). However, it has also been found in other studies that the gap approach, operationalised by 'following procedures and rules within the workplace', also contributes positively to talent retention, though to a much smaller extent (Abrams et al., 2008; Christiaensen et al., 2009; Van Hamme, 2009). In this study we will try to clarify the relationship between the learning and working climate and employee retention.

\section{The present study}

The aim of this study is to investigate some factors that have an influence on employee retention. Based on the literature and previous research, both employee and organisational factors are taken into account. On the organisational side, the focus is on the learning and working climate, which has been operationalised in terms of the two approaches discussed above - the gap and appreciative approaches. It is expected that the appreciative approach will contribute more positively to employee retention than the gap approach because, in the former approach, employees are more acknowledged

\section{Influence of
learning \\ Influence of
learning}

39 
JWL 23,1

for their strengths, and this creates the drive for developing their talents. On the employee side, age, seniority and level of education are included in this research to find out what their relationship with employee retention is. Previous research on the association between age, seniority and the level of education with employee retention has not offered a clear conclusion. Therefore, no concrete expectations are formulated for these variables. Other employee variables, such as leadership skills, learning attitudes, creativity and autonomy are included in this research in order to be able to make a distinction between High Potentials and non High Potentials. The expectation is that High Potentials will have a higher retention rate relative to non High Potentials, since it is common for companies to invest more in high potential employees than in other employees (Cope, 1998; Dries and Pepermans, 2008). In addition to which factors have an influence on employee retention, we will also investigate whether differences exist between different kinds of groups of employees in terms of their retention. Groups that are distinguished differ in terms of the employee characteristics of seniority, level of education and being considered as being High Potential or not.

Based on the above, the following research questions have been formulated:

$R Q 1$. To what extent can retention be predicted by the variable "learning and working climate"?

$R Q 2$. What is the relationship between selected employee variables (age, seniority, level of education) and retention?

RQ3. Is there a difference between different groups of employees (groups differing in seniority, level of education and whether or not being seen as High Potential) regarding their retention?

\section{Method}

\subsection{Participants}

Data were collected by means of a questionnaire that was distributed on a voluntary basis in professional organisations and among employees, both electronically and in hard-copy, during 2008-2009. The study sample consisted of 972 employees, mainly clerks, from diverse profit and social-profit organisations. These organisations cover the following sectors: e.g. (tele)communication, child care and home care, manufacturing, ICT, pharmaceutical engineering, banking and nursing. Participants were 52.9 per cent male and 47.1 per cent female. The majority of the employees worked full-time (82.5 per cent), 12.4 per cent worked part-time, and 2.3 per cent had a temporary contract. The remaining 2.8 per cent indicated that they were employed under another type of contract. Up to 30.2 per cent of the participants had only a secondary education qualification. Of those who attended higher education, 43.2 per cent had a Bachelor's degree and 24.3 per cent had a Master's degree. 0.7 per cent had only an elementary education qualification and 1.6 per cent had another type of diploma. Regarding age, the sample was quite evenly spread. 85.2 per cent of the participants were between 20 and 50 years of age. The largest group of participants (18.3 per cent) consisted of people between 26 and 30 years of age. The majority of the sample (74 per cent) had a seniority of less than 15 years. Participants with seniority between one and five years made up the largest group (36.9 per cent). 


\subsection{Instruments}

The questionnaire for this study was based on the questionnaire developed by Bernsen et al. (2009) and was supplemented by items based on the studies of Arnold (2005), Hytter (2007), Kassim (2006), Lindsey and Kleiner (2005), Stone and Liyanearachchi (2006), Whitt (2006), Conner (2000), Dries and Pepermans (2008), Lombardo and Eichinger (2000), Pepermans et al. (2003) and Snipes (2005). The questionnaire as constructed has already been used in the previous research of Abrams et al. (2008), Kyndt et al. (2009) and Christiaensen et al. (2009). The questionnaire consisted of 69 items in which the perception of the participants is central. The items measure the participants' perception of the learning and working climate in their organisation. Since, in general, employers are not willing to release information about their High Potentials (Dries and Pepermans, 2008), the employees themselves were also questioned about the characteristics of High Potentials. These are characterised according to the literature in terms of creativity, leadership skills, learning attitude and autonomy. Finally, a last category of items referred to retention (e.g. If it were up to me, I will definitely be working for this company for the next five years; It does not matter if I am working for this company or another, as long as I have work; I am planning on working for another company within a period of three years). All 69 items were scored on a five-point Likert scale ranging from 1 "I strongly disagree" to 5 "I strongly agree". The items with regard to the independent variables can be found in the Appendix (see Table AII).

\subsection{Analysis}

Two exploratory factor analyses were performed to reduce the number of variables and to look for the underlying structure of the data. The factor analyses were carried out using a maximum likelihood method with varimax rotation. The number of factors was determined by the scree plot criterion and the explained variance of the factors. Items that did not load significantly on any factor (loadings smaller than 0.30 ) or were loaded double (difference in loadings less than 0.20) were excluded from further analysis. A first factor analysis was performed for dependent variable employee retention. The second factor analysis was performed for the independent variables learning and working climate and the characteristics of High Potentials. The data for the factor analysis of employee retention have a determinant of 0.067 , a Kaiser-Meyer-Olkin measure of sampling adequacy of 0.828, and a Bartlett's test of sphericity with a significance of $p<0.001$. The data for the second factor analysis have a determinant of 0.000 , a Kaiser-Meyer-Olkin measure of sampling adequacy of 0.905 , and a Bartlett's test of sphericity with a significance of $p<0.001$. These statistics show that the data are suitable for factor analysis. Next, the reliability of the scales was tested. Subsequently, a stepwise multiple linear regression was used to determine the relation between the independent variables and the dependent variable of employee retention. Finally, a series of one-way ANOVA's was calculated. Retention was compared for different groups of employees: One-way ANOVA's were performed for seniority, the level of education, and being considered as a High Potential or not. However, this latter aspect, could not be answered in a straightforward fashion, because the factor analysis did not provide a clear factor that captured the concept "High Potential". Since the factors "Learning attitude and creativity" and "Leadership skills" are however associated with High Potentials, the scores on these factors were used to divide participants into High Potentials and non High Potentials. If participants

\section{Influence of learning}


JWL 23,1 scored 4 or higher on both factors, they were considered as being High Potentials. Consequently, these two emerging groups were entered in a one-way ANOVA to be able to explore whether differences exist between High Potentials and other employees.

\section{Results}

4.1 Exploratory factor analysis

The factor analysis of the items measuring the dependent variable employee retention resulted in two factors which explain 45.9 per cent of the variance. The first factor "Intention to stay" $(\alpha=0.82)$ contains six items and explains 29.6 per cent of the variance. The second factor "Intention to leave" $(\alpha=0.71)$ contains three items and explains 16.3 per cent of the variance. In total, two of the 11 items were excluded from the analysis. Based on previous research, the two factor solution was not expected, although it can be explained by considering retention as a concept with two underlying dimensions, namely the intention to stay at the present organisation and the intention to leave the present organisation. The second factor analysis pertaining to the items of the independent variables, resulted in five factors that explain 36.98 per cent of the variance. The first factor "Appreciative learning and working climate" $(\alpha=0.91)$ explains 14.9 per cent of the variance and contains items concerning appreciative climate and the stimulation of personal development. The second factor is "Leadership Skills" $(\alpha=0.83)$ and explains 7.2 per cent of the variance. The items loading on this factor all elicited data about the employees' communication competence, his stress proneness, and his interest and abilities in taking up a leader's role within the organisation. The third factor is called "Learning attitude and creativity" $(\alpha=0.73)$ and explains 5.55 per cent of the variance. Items loading on this factor refer to readiness to learn, initiative with regard to learning and employee's use of creativity while performing their job. The fourth factor "Work pressure" ( $\alpha=0.76)$ explains 4.87 per cent of the variance. All items concern pressure of work. The fifth and last factor is called "Following procedures" $(\alpha=0.67)$. This last factor contains items about procedures, rules, and working methods within the organisation. It explains 4.44 per cent of the variance. In total, 12 items were excluded from the final analysis. The deletion of these items led to an increase in the total amount of explained variance. An overview of factor loadings and items can be found in the Appendix (see Tables AI and AII). The factors that came out of the second factor analysis for the independent variables do not represent the two approaches with regard to the learning and work climate as they were found in the literature. However, they do represent aspects of the learning and working climate that can be attributed to one of the two approaches. "Appreciative working and learning climate" relates to the appreciative approach and "Following procedures" relates to the gap approach.

\subsection{Influence of the learning and working climate on retention}

The regression analysis was started with retention as the dependent variable. Because this variable resulted in two factors in the factor analysis, two separate multiple stepwise regression analyses were conducted. The first regression was conducted with "Intention to stay" as the dependent variable and eight independent variables; the five above-mentioned factors, and age, level of education and seniority. The resulting model contained five independent variables (see Table I) which are good predictors of the intention to stay. In total, the model explained 43.8 per cent of the variance 


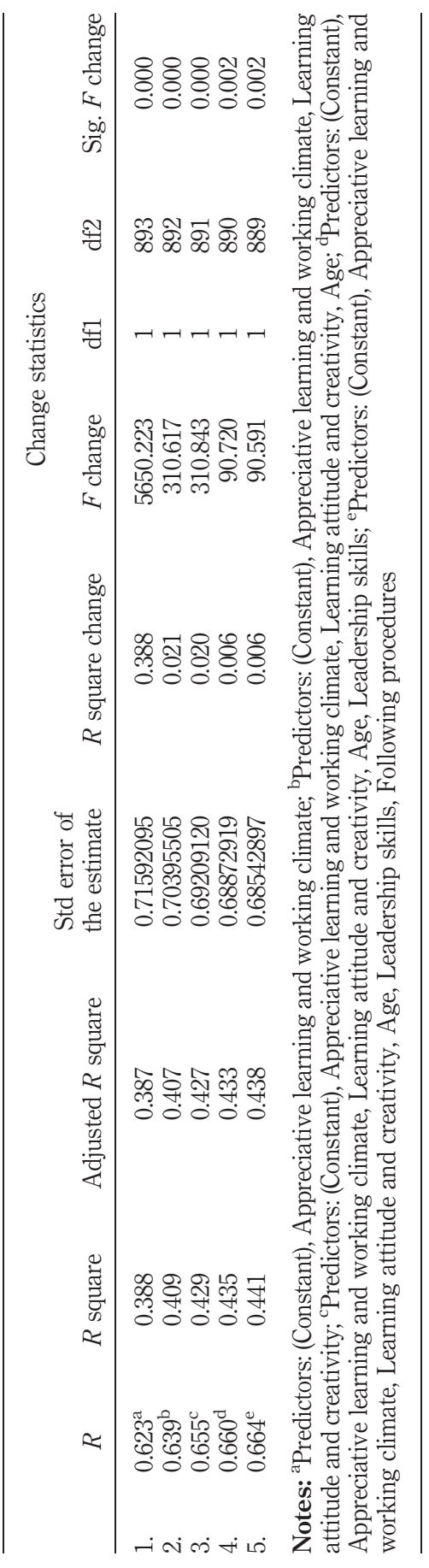

Influence of
learning

43

Table I.

Model summary of multiple stepwise regression analysis of intention to stay 
JWL 23,1

\section{4}

Table II.

Excluded variables from the regression model of intention to stay
$(F=140.37, \mathrm{df}=(5.889), p<0.001)$. "Appreciative learning and working climate" alone explains 38.7 per cent of the variance, while the other variables add less. Variables that were excluded from the model are summed up in Table II.

The model of this first regression concerning the "intention to stay" indicates that an appreciative learning and working climate is a good predictor of intention to stay $(t=24.723, p<0.001, \beta=0.622)$. This means that employees who get sufficient learning opportunities within their organisation and have the feeling that they are appreciated by their superiors and colleagues, tend to stay working in the organisation. The variable has a high $\beta$-coefficient $(\beta=0.622)$ which shows that an "Appreciative learning and working climate" has a large predictive value for the intention to stay. The $\beta$-coefficients of the other variables are considerably smaller and thus have a lower predictive value. "Following procedures" is a variable which is also related to the learning and working climate and which also appears to be a predictor of the intention to stay. "Following procedures" positively influences the intention to stay $(t=3.097$, $p<0.005, \beta=0.078)$. This variable indicates that a strictly organised working place contributes positively to the intention to stay. Hence, results show that, for a considerable part, the intention to stay can be predicted by the learning and working climate. Table III shows all information regarding the coefficients of this first stepwise regression with "intention to stay" as the dependent variable.

The second regression analysis was set up with "Intention to leave" as the dependent variable and the same eight independent variables as in the first regression analysis. Unlike the previous regression model, only four variables were withheld in the final model (see Table IV). This model explained merely 5.2 per cent of the variance $(F=13.22, \mathrm{df}=(4.890), p<0.001)$, indicating that the four variables that were included in the model do have an influence on the intention to leave, but that there are other variables which have a greater effect. Yet, which variables these are cannot be inferred from this research. However, the variables that were excluded from this model,

\begin{tabular}{lrrccc}
\hline & & & & & Collinearity statistics \\
& Beta ln & \multicolumn{1}{c}{$t$} & Sig. & Partial correlation & \begin{tabular}{c} 
Tolerance \\
\hline Seniority
\end{tabular} \\
Level of education & -0.018 & 0.471 & 0.638 & 0.016 & 0.424 \\
Work pressure & -0.037 & -1.824 & 0.069 & -0.061 & 0.887 \\
& & & 0.145 & -0.049 & 0.969 \\
\hline
\end{tabular}

Table III.

Multiple stepwise linear regression on intention to stay: coefficients

\begin{tabular}{|c|c|c|c|c|c|}
\hline & \multicolumn{2}{|c|}{$\begin{array}{l}\text { Unstandardized } \\
\text { coefficients }\end{array}$} & \multirow{2}{*}{$\begin{array}{l}\text { Standardized } \\
\text { coefficients } \\
\text { Beta }\end{array}$} & \multirow[b]{2}{*}{$t$} & \multirow[b]{2}{*}{ Sig. } \\
\hline & B & Std error & & & \\
\hline (Constant) & -0.260 & 0.057 & & -4.605 & 0.000 \\
\hline Appreciative learning and working climate & 0.596 & 0.024 & 0.622 & 24.723 & 0.000 \\
\hline Learning attitude and creativity & 0.151 & 0.027 & 0.141 & 5.604 & 0.000 \\
\hline Age & 0.055 & 0.011 & 0.129 & 5.076 & 0.000 \\
\hline Leadership skills & 0.083 & 0.025 & 0.083 & 3.262 & 0.001 \\
\hline Following procedures & 0.082 & 0.027 & 0.078 & 30.097 & 0.002 \\
\hline
\end{tabular}




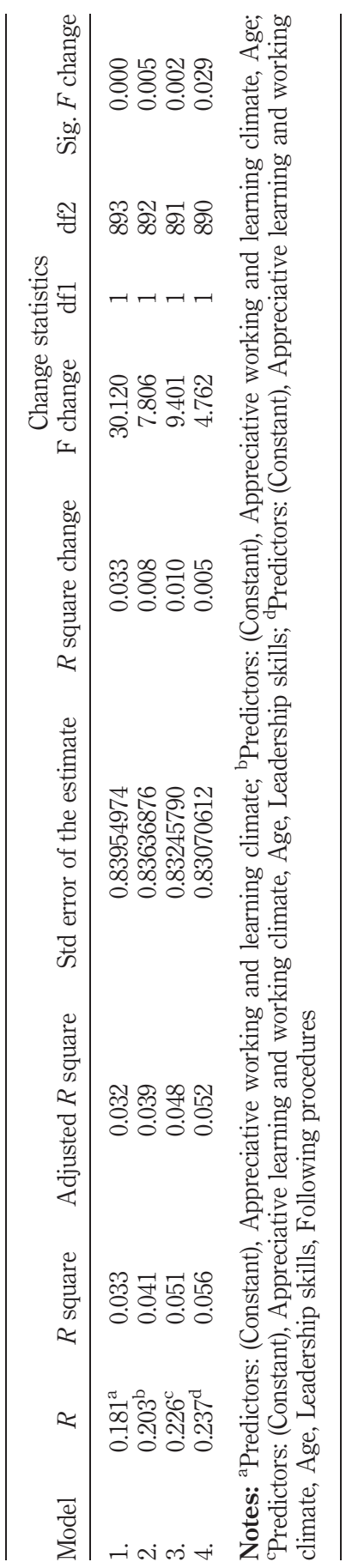

Influence of learning

45

Table IV.

Model summary of multiple stepwise regression analysis of intention to leave 
JWL

23,1

46

Table V.

Excluded variables from the regression model of intention to leave

and therefore do not have a significant predictive value for intention to leave, are summed up in Table V.

It appears from this second regression model that an "Appreciative learning and working climate" relates negatively to the intention to leave $(t=-5.863, p<0.001$, $\beta=-0.191)$. This means that establishing a learning and working climate wherein employees perceive that they are being appreciated and that chances to learn are being offered to them, the intention to leave will be smaller. "Following procedures" is another predictor that negatively influences the intention to leave $(t=-2.182$, $p=0.029, \beta=-0.071$ ). When the working environment is regulated by rules and procedures, employees tend not to leave the present organisation. However, it has to be stressed that the beta coefficients in this analysis are very small, and that they should be interpreted with caution (see Table VI). Results here show that from the variables that were included in this regression analysis, an appreciative learning and working climate is the best predictor of the intention to leave the organisation. This variable and "Following procedures" - the two variables relating to the learning and working climate - appear to be predictors of the intention to leave. Therefore the intention to leave can be predicted by the learning and working climate, though to a very small extent.

\subsection{Influence of age, seniority and level of education on retention}

Results pertaining to the second research question show a significant positive influence of age on the intention to stay ( $t=5.076, p<0.001, \beta=0.129)$. This means that older employees are more likely to stay working in the present organisation than are younger employees. On the other hand, the multiple stepwise regression shows a significant negative influence of age on the intention to leave $(t=-3.172, p<0.005$, $\beta=-0.105$ ) (see Table VI). In effect, this means that older the employees are, the less they are likely to leave the organisation. In the stepwise regression analysis, seniority

\begin{tabular}{lrrccc}
\hline Model & Beta ln & \multicolumn{1}{c}{$t$} & Sig. & Partial correlation & $\begin{array}{c}\text { Collinearity statistics } \\
\text { Tolerance }\end{array}$ \\
\hline Seniority & 0.018 & 0.368 & 0.713 & 0.012 & 0.434 \\
Level of education & 0.060 & 1.798 & 0.073 & 0.060 & 0.942 \\
Learning attitude and creativity & -0.013 & -0.393 & 0.695 & -0.013 & 0.988 \\
Work pressure & 0.024 & 0.722 & 0.471 & 0.024 & 0.969 \\
\hline
\end{tabular}

\section{Table VI.}

Multiple stepwise linear regression on intention to leave: coefficients

\begin{tabular}{|c|c|c|c|c|c|}
\hline \multirow[b]{2}{*}{ Model } & \multicolumn{2}{|c|}{$\begin{array}{l}\text { Unstandardized } \\
\text { coefficients }\end{array}$} & \multirow{2}{*}{$\begin{array}{l}\text { Standardized } \\
\text { coefficients } \\
\text { Beta }\end{array}$} & \multirow[b]{2}{*}{$t$} & \multirow[b]{2}{*}{ Sig. } \\
\hline & $\mathrm{B}$ & Std error & & & \\
\hline (Constant) & 0.203 & 0.069 & & 2.957 & 0.003 \\
\hline Appreciative learning and working climate & -0.171 & 0.029 & -0.191 & -5.863 & 0.000 \\
\hline Age & -0.042 & 0.013 & -0.105 & -3.172 & 0.002 \\
\hline Leadership skills & 0.092 & 0.031 & 0.098 & 2.977 & 0.003 \\
\hline Following procedures & -0.070 & 0.032 & -0.071 & -2.182 & 0.029 \\
\hline
\end{tabular}


was excluded from the models because of its high correlation with age $(\rho=0.747, p<$ 0.001). Besides seniority, the level of education was also excluded from the models.

\subsection{Differences between groups of employees regarding their retention}

Finally, whether differences exist between different groups of employees regarding their retention was explored. The groups of employees differed in seniority, level of education and being considered as having High Potential or not. However, the two factors, "Leadership skills" and "Learning attitude and creativity", that are associated with High Potential also have an influence on retention. On the one hand, "Learning attitude and creativity" positively influences the intention to stay $(t=5.604, p<0.001$, $\beta=0.141$ ), indicating that employees who score high on this feature are more likely to stay. The same goes for 'Leadership skills' $(t=3.262, p<0.005, \beta=0.083)$. So, if employees perceive themselves to be communicative, immune to stress and having an interest in taking on a leader's role within the company, the likelihood of employee retention will be relatively high. With regard to the intention to leave, 'Leadership skills' has a positive influence $(t=2.977, p<0.005, \beta=0.098)$. Apparently, when employees consider themselves as potential leaders, the likelihood of leaving the organisation is also present, although it appears from the first regression model that 'Leadership skills' also has a positive influence on intention to stay (see Tables III and VI).

Separate ANOVA's were carried out for the different groups of employees and their intention to stay, on the one hand, and their intention to leave on the other. The first series of ANOVA's focused on the intention to stay. It showed that significant differences exist between High Potentials and non High Potentials. High Potentials score significantly higher on intention to stay than non High Potentials $(F=27.412$, $\left.\mathrm{df}=(1.925), p<0.001, \eta^{2}=0.03\right)$. Significant differences were also found between employees with different levels of seniority. It appeared that employees with more than 20 years seniority, the highest level, score highest on terms of intention to stay. Employees with less than five years seniority, the lowest level, scored the lowest $\left(F=3.372, \mathrm{df}=(2.939), p=0.035, \eta^{2}=0.007\right)$. In the second series of ANOVA's, differences existing between groups of employees was examined regarding their intention to leave. No significant differences were found between employees who differed in seniority, level of education or being considered as a High Potential or not.

\section{Conclusion and discussion}

With regard of the first research question "To what extent can retention be predicted by the variable "learning and working climate'?", it can be concluded that an "Appreciative learning and working climate" has the most predictive value in terms of retention. This was in line with expectations, and confirmed the results of previous research by Abrams et al. (2008), Kyndt et al. (2009), Christiaensen et al. (2009) and Van Hamme (2009). However, "Following procedures" influences retention also, which is also confirmed by the previously cited research, with the exception of Kyndt et al. (2009) who did not identify "Following procedures" as a significant predictor of employee retention. It appears that in this study, evidence can be found for the assumption that elements of both the gap and the appreciative approach matter in employee retention. Hence, a possible explanation could be that employees appreciate a certain amount of freedom but, at the same time, rely on the security and support of

\section{Influence of learning}


JWL 23,1 existing procedures. However, it is important to note that the influence of the factors "Appreciative learning and working climate", and "Following procedures" differs in terms of the intention to stay and the intention to leave. Considering the intention to stay, both "Appreciative learning and working climate" and "Following procedures", have a positive influence. In the case of the intention to leave, the predictors operate in the opposite direction, thus having a negative influence. Therefore, establishing an appreciative learning and working climate, together with some rules and procedures to follow, increases the intention to continue working in the present organisation. In contrast, the absence of these two factors will increase the intention to leave. This research shows that when organisations want to retain their employees it is important to pay attention to the learning of employees. Employees who experience an appreciative learning climate in their organisation are more inclined to keep on working in that organisation. In practice, a company can create such an appreciative learning climate by focusing on the strengths of its employees and giving them the chance to apply and develop those strengths. In sum, letting people do more and learn more of what they are good at will encourage them to stay with the organisation. However, it is important to let the ambition of the employee and to let his qualities be the engine for the development process (Tjepkema and Verheijen, 2005). When offering learning opportunities to employees (formal or informal), the interests and qualities of the employee should determine which learning opportunities the employee takes up. Finally, it is important for the employee that the organisation appreciates these learning activities. The functional leader of the employee can express this appreciation and the organisation can offer possibilities for the employee to share his knowledge and skills which can in turn can lead to the appreciation of colleagues. Such elements will increase the intention to retention of the employee which will benefit the organisation.

Results concerning the selected employee variables show that only age has a significant relationship with retention. Regarding the intention to stay, there exists a positive relationship between age and retention. In the case of leaving, a negative relationship is shown. Hence, the older an employee, the more likely he is to stay and the less likely he is to leave the organisation. This is consistent with the findings of previous research where it was found that employees of a younger age were significantly more likely to leave their current job or organisation than older employees (Hellman, 1997; Ito et al., 2001). This finding is not surprising, considering the present societal context wherein it is not easy for an older employee to find another job. Moreover, it is more common for young employees to change jobs at the beginning of their career, which could explain the opposite relation of retention and young age. For the other employee characteristics, seniority and level of education, there does not appear to be a significant relationship with retention. Results of previous studies (Christiaensen et al., 2009; Kyndt et al., 2009; Van Hamme, 2009) were not univocal with regard to the variables, age and seniority. It cannot be concluded which of the two, age or seniority, is of greater importance in relation to retention. Since seniority and age are highly correlated in reality, the stepwise regression analysis will exclude one of the two variables from the analysis. Another remarkable finding was that the level of education had no significant influence on retention. Previous research by Christiaensen et al. (2009) and Kyndt et al. (2009) found a negative relationship between the level of education and retention. This study could not confirm their results. 
Considering the factors "Learning attitude and creativity" and "Leadership skills" as additional employee characteristics, it should be noted that these factors have a positive relationship with intention to stay. For intention to leave there only exists a positive relationship with "Leadership skills", and none with "Learning attitude and creativity". So, the more eager an employee is to learn, and the more creative solutions he uses, the more likely he is to stay working in the organisation. For 'Leadership skills', the relationship is not so clear. It proves that considering oneself as a potential leader both influences the intention to stay and the intention to leave. A possible explanation could be that leadership skills cohere with other personality traits which influence retention, or that leadership skills are related to job characteristics. In this latter case, when an employee does not consider his leadership skills to be useful in the present job and organisation, he can decide to leave or, when they do seem to matter, he is more likely to stay and decide to move up in the organisation. Future research can investigate this dual relationship between leadership skills and retention.

For the last research question "Is there a difference between different groups of employees and their retention?" it was found that some groups of employees differed with regard to their retention. Considering the intention to stay, there appears to be significant differences between employees with different levels of seniority and between High Potentials and non High Potentials. Employees with more than twenty years seniority score higher on intention to stay than employees with less seniority. This result was also found in the study of Ito et al. (2001), where time in current job was significantly longer among those employees intending to stay, than among those intending to leave their job. An explanation could be found in the fact that, as tenure increases within an organisation, so does the employee's potential for both formal benefits such as promotion, and informal benefits such as status among the less experienced co-workers. This could therefore explain why employees with higher levels of seniority are more likely to stay within the same organisation, because otherwise they would lose the benefits they have obtained and they may have to re-establish their value in a new organisation (Hellman, 1997). Results also proved that High Potentials are more likely to stay than non High Potentials. This difference between High Potentials and non High Potentials is in line with what Van Hamme (2009) found in his research. Looking at the intention to leave, no differences were found between employees of different groups. The results of these ANOVA's cannot be compared with previous published research. However, the results of the ANOVA's conducted in this study should be interpreted with caution, because the sample sizes of the different groups of employees were not equal, which could have biased the results.

A limitation of this study is that both employee as organizational factors are measured through the perceptions of employees. The response set of subjects when responding to self-report measures could therefore be the result of a temporary mood, or could be the result of what may be considered as socially appropriate by the participants. Another limitation is that the questionnaire was voluntarily completed by the respondents; the researcher had therefore no information about the non-respondents. It is possible that companies that refused to participate, as well as employees who chose not to respond to the study's questionnaire, were those who were less motivated, less satisfied and/or less reflective with their job and workplace, what could have biased the results. The fact that the questionnaire was completed on a voluntary basis led to a relatively high percentage (67.5 per cent) of participants with a

\section{Influence of learning}


JWL 23,1 degree in higher education (Bachelor or Master) in comparison with the employed population or labour force in Belgium (39.4 per cent), where the research was conducted (Steunpunt WSE, 2009). In general these employees are more willing to participate in this type of research that makes use of questionnaires which are not always suited for employees with a lower level of education (Champion and Sear, 1968).

In general, it is remarkable that the same variables, with the exception of "Learning attitude and creativity", predict the intention to stay as well as the intention to leave. This is true even though the proportion explained variance of these variables is much smaller when predicting the intention to leave, and the relationships occur in a reversed way, with the exception of the variable "Leadership skills". However, the identified predictors influence both the intention to stay as well as the intention to leave, but more appropriate variables should be found to predict the intention to leave. Other research has repeatedly identified job satisfaction and/or organisational commitment as having a negative predictive relationship with the intention to leave (Acker, 2004; Armstrong-Stassen and Ursel, 2009; Currivan, 1999; Mosadeghrad et al., 2008; Larrabee et al., 2003; Loi et al., 2006; Vandenberghe and Bentein, 2009). Future research therefore needs to examine the effects of this variable, which was not measured in the current study, on the intention to leave.

\section{References}

Abrams, J., Castermans, S., Cools, H., Michielsen, M., Moeyaert, B., Van Meeuwen, N. and VanNooten, L. (2008), "Leren en talent management: factoren die het behouden van (talentvolle) werknemers beïnvloeden" ("Learning and talent management: factors which influence the retention of (talented) employees"), unpublished research report, Faculty of Psychology and Educational Sciences, University of Leuven, Leuven.

Acker, G. (2004), "The effect of organizational conditions (role conflict, role ambiguity, opportunities for professional development, and social support) on job satisfaction and intention to leave among social workers in mental health care", Community Mental Health Journal, Vol. 40 No. 1, pp. 65-73.

Argyris, C. (2001), On Organizational Learning, 2nd ed., Blackwell Business, Oxford.

Armstrong-Stassen, M. and Ursel, N.D. (2009), "Perceived organizational support, career satisfaction, and the retention of older workers", Journal of Occupational and Organizational Psychology, Vol. 82 No. 1, pp. 201-20.

Arnold, E. (2005), "Managing human resources to improve employee retention”, The Health Care Manager, Vol. 24 No. 2, pp. 132-40.

Barab, S.A. and Plucker, J.A. (2002), "Smart people or smart contexts? Cognition, ability and talent development in an age of situated approaches to knowing and learning", Educational Psychologist, Vol. 37 No. 3, pp. 165-82.

Bernsen, P., Segers, M. and Tillema, H. (2009), "Learning under pressure: learning strategies, workplace climate, and leadership style in the hospitality industry", International Journal of Human Resource Development and Management, Vol. 9 No. 4, pp. 358-73.

Bexell, A. and Olofsson, F. (2005), available at: http://hj.divaportal.org/smash/record. jsf?searchId=1andpid=diva2:3778 (accessed October 20, 2009).

Birt, M., Wallis, T. and Winternitz, G. (2004), "Talent retention in a changing workplace: an investigation of variables considered important to South African talent", South African Journal of Business Management, Vol. 35 No. 2, pp. 25-31. 
Bouwmans, M. (2006), "Verhalen die ons motiveren" ("Stories that motivate us"), available at: http://appreciativeinquiry.case.edu/uploads/pdf_BROCHURE_68.pdf (accessed October 20, 2009).

Burke, R. and Ng, E. (2006), "The changing nature of work and organizations: implications for human resource management”, Human Resource Management Review, Vol. 16 No. 2, pp. 86-94.

Champion, D.J. and Sear, A.M. (1968), "Questionnaire response rate: a methodological analysis", Social Forces, Vol. 47, pp. 335-39.

Christiaensen, R., Kinschots, C., Marcelis, V., Philips, K., VanCauwenberghe, H., Van den Bogaert, T. and Vervaeke, A. (2009), "Retentie van getalenteerde werknemers: het belang van leer- en werkklimaat", ("Retention of talented employees: the importance of the learning and working climate"), unpublished research report supervised by F. Dochy and H. Baert, Faculty of Psychology and Educational Sciences, University of Leuven, Leuven.

Conner, J. (2000), "Developing the global leaders of tomorrow", Human Resource Management, Vol. 39 Nos 2/3, pp. 147-57.

Cooperrider, D.L. and Whitney, D.K. (2005), Appreciative Inquiry: A Positive Revolution in Change, Berrett-Koeler, San Francisco, CA.

Cooperrider, D.L., Whitney, D.K. and Stavros, J.M. (2007), Appreciative Inquiry Handbook: The First in a Series of AI Workbooks for Leaders of Change, 2nd ed., Berrett-Koehler, San Francisco, CA.

Cope, F. (1998), "Current issues in selecting high potentials", Human Resource Planning, Vol. 21 No. 3, pp. 15-17.

Currivan, D. (1999), "The causal order of job satisfaction and organizational commitment in models of employee turnover", Human Resource Management Review, Vol. 9 No. 4, pp. 495-524.

Dries, N. and Pepermans, R. (2007), "Using emotional intelligence to identify high potential: a metacompetency perspective", Leadership and Organization Development Journal, Vol. 28 No. 8, pp. 749-70.

Dries, N. and Pepermans, R. (2008), "Real high-potential careers: an empirical study into the perspectives of organisations and "High Potentials", Personnel Review, Vol. 37 No. 1, pp. 85-108.

Echols, M.E. (2007), "Learning's role in talent management”, Chief Learning Officer, Vol. 6 No. 10, pp. 36-40.

Fishman, C. (1998), "The war for talent”, available at: www.retirementcapital.com/ knowledgecenter/magazine/vol4no1/main.pdf (accessed October 20, 2009).

Frank, F.D., Finnegan, R.P. and Taylor, C.R. (2004), "The race for talent: retaining and engaging workers in the 21st century”, Human Resource Planning, Vol. 27 No. 3, pp. 12-25.

Gijbels, D. and Spaenhoven, R. (2011), "On Argyris' organizational learning”, in Dochy, F., Gijbels, D., Segers, M. and Van den Bossche, P. (Eds), Theories of Learning in the Professions: Buiding Blocks for Training and Professional Development Programs, Routledge, London.

Glen, C. (2007), "Fostering talent opportunity: getting past first-base", Strategic Direction, Vol. 23 No. 10 , pp. $3-5$.

Gunz, H. and Gunz, S. (2007), "Hired professional to hired gun: an identity theory approach to understanding the ethical behaviour of professionals in non-professional organizations", Human Relations, Vol. 60 No. 6, pp. 851-87.

Hellman, C. (1997), "Job satisfaction and intent to leave", The Journal of Social Psychology, Vol. 137 No. 6, pp. 677-89.

\section{Influence of learning}


JWL 23,1

Herman, R.E. (2005), "HR managers as employee-retention specialists", Employment Relations Today, Vol. 32 No. 2, pp. 1-7.

Hiltrop, J.M. (1999), "The quest for the best: human resource practices to attract and retain talent”, European Management Journal, Vol. 17 No. 4, pp. 422-30.

Houtkamp, P. and Marée, O. (2008), "Vakmanschap is meesterschap", ("Craftmanship is mastery"), Gids voor personeelsmanagement, Vol. 87 No. 9, pp. 50-55.

Hytter, A. (2007), "Retention strategies in France and Sweden", The Irish Journal of Management, Vol. 28 No. 1, pp. 59-79.

Ingham, J. (2006), "Closing the talent management gap: harnessing your employees' talent to deliver optimum business performance", Strategic Human Resource Review, Vol. 5 No. 3, pp. 20-3.

Ito, H., Eisen, S., Sederer, L., Yamada, O. and Tachimori, H. (2001), "Factors affecting psychiatric nurses' intention to leave their current job", Psychiatric Services, Vol. 52 No. 2, pp. 232-4.

Kassim, N.M. (2006), "Telecommunication industry in Malaysia: demographic effects on costumer expectations, performance, satisfaction and retention”, Asia Pacific Business Review, Vol. 12 No. 4, pp. 437-63.

Kyndt, E., Dochy, F., Michielsen, M. and Moeyaert, B. (2009), "Employee retention: organisational and personal perspectives", Vocations and Learning, Vol. 2 No. 3, pp. 195-215.

Larrabee, J., Janney, M., Ostrow, C., Withrow, M.L., Hobbs, G. and Burant, C. (2003), "Predicting registered nurse job satisfaction and intent to leave", Journal of Nursing Administration, Vol. 33 No. 5, pp. 271-83.

Lindsey, G. and Kleiner, B. (2005), "Nurse residency program: an effective tool for recruitment and retention", Journal of Health Care Finance, Vol. 31 No. 3, pp. 25-32.

Lockwood, N.R. (2006), "Talent management: driver for organizational success”, SHRM Research Quarterly, Vol. 51 No. 6, pp. 1-11.

Loi, R., Hang-yue, N. and Foley, S. (2006), "Linking employees' justice perceptions to organizational commitment and intention to leave: the mediating role of perceived organizational support", Journal of Occupational and Organizational Psychology, Vol. 79 No. 1, pp. 101-20.

Lombardo, M. and Eichinger, R. (2000), “High potentials' as high learners”, Human Resource Management, Vol. 39 No. 4, pp. 321-9.

Michaels, E., Handfield-Jones, H. and Axelrod, B. (2001), The War for Talent, Harvard Business School Press, Boston, MA.

Mosadeghrad, A.M., Ferlie, E. and Rosenberg, D. (2008), “A study of the relationship between job satisfaction, organizational commitment and turnover intention among hospital employees", Health Services Management Research, Vol. 21 No. 4, pp. 211-27.

Peck, C.A., Galucci, C., Sloan, T. and Lippincott, A. (2009), "Organisational learning and program renewal in teacher education: a socio-cultural theory of learning, innovation and change", Educational Research Review, Vol. 4 No. 1, pp. 16-25.

Pepermans, R., Vloeberghs, D. and Perkisas, B. (2003), "High potential identification policies: an empirical study among Belgian companies", Journal of Management Development, Vol. 22 No. 8, pp. 660-78.

Rodriguez, R. (2008), "Learning's impact on talent flow", Chief Learning Officer, Vol. 7 No. 4, pp. 50-64.

Simonton, D.K. (1999), "Talent and its development: An emergenic and epigenetic model", Psychological Review, Vol. 106 No. 3, pp. 435-57. 
Snipes, J. (2005), "Identifying and cultivating high-potential employees", Chief Learning Officer Magazine, pp. 1-6.

Steunpunt WSE (2009), Labour Force Survey, fwww.steunpuntwse.be/view/n1/18767 (accessed September 14, 2010)

Stone, M. and Liyanearachchi, D. (2006), "Managing retention, who does it well?", Journal of Database Marketing and Customer Strategy Management, Vol. 14, pp. 90-103.

Thorne, K. and Pellant, A. (2007), The Essential Guide to Managing Talent. How Top Companies Recruit, Train and Retain the Best Employees, Kogan Page, London, Philadelphia, PA.

Tjepkema, S. and Verheijen, L. (2005), "Ontwikkelen van(uit) talent: een krachtig perspectief voor persoonlijke groei”, ("Developing talent: a powerful perspective for personal growth”), Gids voor personeelsmanagement, Vol. 84 No. 5, pp.24-27.

Vandenberghe, C. and Bentein, K. (2009), "A closer look at the relationship between affective commitment to supervisors and organizations and turnover", Journal of Occupational and Organizational Psychology, Vol. 82, pp. 331-48.

Van Hamme, S. (2009), "Talent development bij werknemers: De relatie tussen leerklimaat en retentie", ("Talent development for employees: the relationship between the learning environment and retention"), unpublished master thesis, Faculty of Psychology and Educational Sciences, University of Leuven.

Verheijen, L. and Dewulf, L. (2004), "Vormgeven aan leren als een relationeel proces", ("Shaping learning as a relational process"), Opleiding and Ontwikkeling, Vol. 11, pp. 25-8.

Visser, C. (2001), "Succesvol verandermanagement door appreciative inquiry”, ("Succesful change management by appreciative inquiry"), available at: http://m-cc.nl/ succesvolverandermanagement.pdf (accessed October 21, 2009).

Walker, J.W. (2001), “Zero defections?”, Human Resource Planning, Vol. 24 No. 1, pp. 6-8.

Whitt, W. (2006), "The impact of increased employee retention on performance in a customer contact center", Manufacturing and Service Operations Management, Vol. 8 No. 3, pp. 235-52.

\section{Appendix. Overview factor loadings}

\begin{tabular}{lll}
\hline & \multicolumn{2}{c}{ Factor } \\
& 1 & 2 \\
\hline Within this company my work gives me satisfaction & 0.739 & \\
If I wanted to do another job or function, I would look first at the & 0.484 \\
possibilities within this company & 0.712 & \\
I see a future for myself within this company & 0.684 \\
If it were up to me, I will definitely be working for this company for & 0.538 \\
the next five years & 0.755 & \\
The work I am doing is very important to me & & 0.612 \\
I love working for this company & & 0.774 \\
I intent, within a period of three years, to go working in another & & 0.616 \\
company & & \\
I have checked out a job in another company previously & & \\
If I received an attractive job offer from another company, I would \\
take the job
\end{tabular}

Notes: Extraction method: Maximum likelihood; Rotation method: Varimax with Kaiser normalization

Table AI. Rotated factor loadings dependent variable employee retention: intention to stay and intention to leave 
JWL

23,1

\begin{tabular}{llllllll}
\hline Factor & & \\
& 1 & 2 & 3 & 4 & 5 \\
\hline
\end{tabular}

The executive staff try to understand the problems employees experience in their work

On the job I have sufficient opportunity to use my personal talents

54 and use my initiative

0.626

The executive staff in this company seem to make an effort to be nice to the employees

At work there seems to be an honest interest in the things I'm doing outside of work

The executive staff in this company always appear to be ready to give advice about how I can learn something new

We can criticise the work regulations and our criticisms are heard 0.562

When reforms are implemented, it's because somebody had a good idea which was implemented

My company gives me the opportunity to get training in subjects that interest me

My company stimulates me to think about where I stand and where I need to get to achieve the company goals

In this company people can really choose what work they want to do

At work I am doing stimulates me to develop myself in things that I am not yet very good at

The company motivates me to develop, if possible, my own workrelated interests

In this company I have the opportunity to organise my work so that it fits the way I learn

There are lots of ways that I can choose to learn $\quad 0.576$

Our ideas and interests are taken serious by executive staff $\quad 0.681$

Most executives make an effort to get to know us $\quad 0.647$

In my job I have the opportunity to do something with my skills and knowledge 0.574

In my job I am stimulated to think about the skills that I am good at 0.630

I can communicate, present and give a speech well.

I can convince everyone of the correctness and necessity of the

ideas and actions I propose and undertake

When I am speaking in a group, I draw everyone's full attention

0.411

0.553

I am able to motivate others to do their tasks as well as possible.

0.479

When I am working in team, I easily take the lead

0.769

I make good decisions, even when I am under pressure.

0.424

I find myself capable of taking on an executive function in this company

0.677

Others in this company see me as someone who takes the lead easily

0.781

When I want to learn something that can be useful in the workplace, I take the initiative

When doing my work I use my creativity and inventiveness

Table AII.

Rotated factor loadings independent variables
Some subjects that arise during work are so interesting that I

investigate them further, even when it is not necessary for my work I love to accept complex and challenging tasks
0.372

0.452

0.534 


\begin{tabular}{|c|c|c|c|c|c|}
\hline & \multicolumn{5}{|c|}{ Factor } \\
\hline & 1 & 2 & 3 & 4 & 5 \\
\hline In solving problems, I try as much as possible to think up & & & & & \\
\hline $\begin{array}{l}\text { alternative solutions } \\
\text { and }\end{array}$ & & & 0.371 & & \\
\hline $\begin{array}{l}\text { I always try to fulfil my task completely, even when this brings } \\
\text { stress with it }\end{array}$ & & & & & \\
\hline $\begin{array}{l}\text { stress with it } \\
\text { If I get the chance to learn, I will definitely take it }\end{array}$ & & & 0.390 & & \\
\hline $\begin{array}{l}\text { If I get the chance to learn, I will definitely take it } \\
\text { I think it is important to learn throughout my life }\end{array}$ & & & $\begin{array}{l}0.039 \\
0.529\end{array}$ & & \\
\hline The work pressure is too high here & & & & 0.745 & \\
\hline I sometimes think that my job asks too many different things of me & & & & 0.498 & \\
\hline $\begin{array}{l}\text { The constant pressure of work - things that need to be done, } \\
\text { deadlines and competition - make me tense and sometimes }\end{array}$ & & & & & \\
\hline depressed & & & & 0.544 & \\
\hline There is a lot of work to do & & & & 0.579 & \\
\hline As an employee I am put under a lot of pressure. & & & & 0.773 & \\
\hline $\begin{array}{l}\text { When I do my work, I follow the instructions closely, even when } \\
\text { they are not in line with my own ideas }\end{array}$ & & & & & 0.483 \\
\hline $\begin{array}{l}\text { When innovations are made, it is usually because management has } \\
\text { decided on a corporate strategy and corporate goals and we then }\end{array}$ & & & & & \\
\hline try to accomplish these goals as well as possible & & & & & 0.429 \\
\hline $\begin{array}{l}\text { In my job it is very important that I do what is expected of me as } \\
\text { closely as possible }\end{array}$ & & & & & 0.529 \\
\hline $\begin{array}{l}\text { Usually when a problem occurs I rely on procedures that are } \\
\text { dictated by the company }\end{array}$ & & & & & 0.539 \\
\hline For a large part, I determine how I work & & & & & 0.408 \\
\hline $\begin{array}{l}\text { For most situations at work, procedures are enforced by the } \\
\text { company }\end{array}$ & & & & & 0.624 \\
\hline
\end{tabular}

Notes: Extraction method: Maximum likelihood; Rotation method: Varimax with Kaiser normalization

Table AII.

\section{About the authors}

Natalie Govaerts obtained her Master's degree in Educational Sciences at the University of Leuven, Belgium. Natalie Govaerts is the corresponding author and can be contacted at: Natalie.Govaerts@ student.kuleuven.be

Eva Kyndt is a $\mathrm{PhD}$ student at the Centre for Research on Teaching and Training at the University of Leuven, Belgium. She is doing her doctoral study on the influence of subjective workload and task complexity on student approaches to learning. Her other research interests are workplace learning and talent management.

Filip Dochy is Professor of Teaching and (Corporate) Training at the Centre for Educational Research on Lifelong Learning and Participation and the Centre for Research on Teaching and Training at the University of Leuven, Belgium. In his research he concentrates on new learning and training environments, new modes of assessment on teaching, and trainers' lifelong learning in teacher training and corporate training settings. He is a former president of the European Association for Research on Learning and Instruction (EARLI, www.earli.org).

Herman Baert is Professor of Lifelong Learning, he is Director of the Centre for Research on Adult and Continuing Education at the University of Leuven, Belgium.

To purchase reprints of this article please e-mail: reprints@emeraldinsight.com Or visit our web site for further details: www.emeraldinsight.com/reprints 